\title{
PRAKTIK TATA KELOLA PERUSAHAAN (CORPORATE GOVERNANCE) DAN USEFULNESS INFORMASI AKUNTANSI (Telaah Teoritis Dan Empiris)
}

\author{
Muhammad Miqdad \\ Fakultas Ekonomi Jurusan Akuntansi, Universitas Jember, Indonesia \\ Email: miq_aset@yahoo.co.id
}

\begin{abstract}
Abstrak
Riset akuntansi yang berkaitan dengan tata kelola perusahaan dan manajemen laba mengacu pada teori akuntansi positif dan teori agensi. Sebagian besar hasil studi empiris menunjukkan bahwa implementasi tata kelola perusaaan yang baik (good corporate governance) berdampak negatif terhadap praktik manajemen laba. Praktik manajemen laba yang berlebihan berdampak negatif terhadap kredibilitas laporan keuangan dari sudut pandang pengguna seperti investor, kreditor dan stakeholders lainnya. Praktik GCG dan manajemen laba berkaitan dengan masalah-masalah perilaku, karena itu metode penelitian kualitatif menjadi alternatif solusi dalam penelitian-penelitian yang berkaitan dengan perilaku.
\end{abstract}

Kata Kunci: Tata Kelola Perusahaan, Manajemen Laba, Teori Akuntansi Positif, Teori Agensi, Riset Kualitatif.

\begin{abstract}
Accounting researchs on corporate governance and earnings management refers to the positive accounting theory and agency theory. Most of the result empirical studies showed that implementing of good corporate governance (GCG) negatively affect to earnings management. Excessive earnings management practices will affect the credibility of the financial statements in the user's perception namely investors, creditors and other stakeholders. Corporate governance and earnings management associated with behavioral problems, therefore qualitative research method as an alternative to explore further of the behavioral problems.
\end{abstract}

Keywords: Corporate Governance, Earnings Management, Positive Accounting Theory, Agency Theory, Qualitative Research.

\section{PENDAHULUAN}

Riset mengenai tata kelola perusahaan (corporate governance) masih menjadi topik yang menarik untuk diteliti seiring dengan terbukanya skandal keuangan berskala besar (misalnya skandal Enron Corp, Tyco, Worldcom Inc., Xerox Corp.,) yang melibatkan akuntan. Dalam kasus Enron, dampak yang jelas adalah kerugian yang ditanggung para investor dari ambruknya nilai saham yang sangat dramatis dari harga per saham US\$ 30 menjadi hanya US\$ 10 dalam waktu dua minggu. Kasus ini memunculkan pertanyaan mengapa suatu perusahaan kelas dunia dapat mengalami hal yang sangat tragis dengan mendeklarasikan bangkrut justru setelah hasil audit keuangan perusahaannya dinyatakan pendapat tanpa kualifikasi (unqualified opinion). Di Indonesia, kasus Lippo merupakan salah satu skandal akuntansi yang sangat menonjol di tahun 2003. Skandal Bank
Lippo adalah berkaitan dengan pelaporan keuangan, dengan diterbitkannya dua versi laporan keuangan, yaitu antara yang diterbitkannya ke Bursa Efek Jakarta dan yang dipublikasikan.

Tahun 2001, hasil survei yang dilakukan oleh Credit Lynonnais Securities (CLSA) pada 115 perusahaan di 25 negara berkembang menunjukkan bahwa skor total untuk perusahaan di Indonesia yang disurvei hanya 37,7 dari skala (skor 0-100). Skor ini lebih rendah dibandingkan dengan skor total perusahaan-perusahaan yang disurvei di Negara Singapura (64,5), Malaysia $(56,6)$, India $(55,6)$, Thailand $(55,1)$, Taiwan $(54,6)$, Cina $(49,1)$, Korea $(47,1)$ dan Filipina $(43,9)$. Makin tinggi skor menunjukkan bahwa ketaatan pada prinsip-prinsip Good Corporate Governance atau GCG (yang meliputi disiplin, transparansi, kemandirian, akuntabilitas, tanggung jawab, keadilan dan kesadaran nasional) makin besar (Zarkasyi, 2008). 
Di Indonesia, praktik GCG telah diatur dalam beberapa undang-undang dan peraturan, sehingga implementasi prinsip-prinsip GCG salah satunya didorong oleh kepatuhan terhadap regulasi (seperti UU PT no 40/2007, peraturan Bapepam-LK, Peraturan Bank Indonesia no 8/4/PBI/2006 yang dirubah menjadi no 8/14/2006 tentang Peraturan GCG bagi bank umum). Hasil riset yang dilakukan oleh The Indonesian Institute for Corporate Governance (IICG) terhadap 52 perusahaan publik (yang masuk dalam LQ45 periode Juli 2000 s/d Juni 2001) menunjukkan bahwa hampir seluruh responden menyatakan arti pentingnya GCG, namun $65 \%$ responden menyatakan menerapkan GCG karena memang regulasi mengehendaki hal tersebut, 30\% menyatakan GCG sebagai bagian dari budaya perusahaan.

Implementasi GCG diharapkan dapat meningkatkan kinerja dan nilai tambah perusahaan. Kinerja perusahaan meningkat berdampak pada kesejahteraan pihak manajemen perusahaan dan pemegang saham (shareholders). Disisi yang lain, pihak manajemen berpotensi melakukan tindakan-tindakan melalui pemilihan kebijakan akuntansi yang berdampak positif pada kepentingan mereka sendiri, dan sangat mungkin terjadi apa yang dilakukan oleh pihak manajemen akan berdampak negatif bagi kepentingan pemilik perusahaan (Jensen dan Meckling, 1976; Fama dan Jensen, 1993; Morck et al. (1989). Karena itu, implementasi GCG adalah menjadi alternatif untuk mengurangi praktik manajemen laba.

Manajemen laba muncul pada saat peneliti akuntansi mencoba mengkaitkan hubungan antara suatu variabel ekonomi tertentu dan upaya manajer untuk mengambil manfaat atas variabel tersebut. Manajemen laba yang berlebihan akan mengurangi manfaat (usefulness) laporan keuangan dalam pandangan penanam modal (Scott, 2009). Magnan dan Cormier (1997) mengungkapkakan bahwa ada tiga alasan utama manajer melakukan praktik manajemen laba yaitu minimalisasi political cost, maksimisasi kesejahteraaan manajer (manager wealth maximization) dan minimisasi biaya (minimization of financing costs).

Efektivitas pelaksanaan corporate governance sangat tergantung dari peran atau actions yang dilakukan oleh elemen-elemen dalam struktur corporate governance. Elemen-elemen tersebut adalah komisaris baik dari unsur independen maupun bukan, komite audit, kepemilikan saham oleh insitusi, kepemilikan saham dan jasa audit dari Kantor Akuntan Publik (KAP) yang bereputasi. Harapannya adalah semakin efektif peran yang dilakukan oleh elemen-elemen struktur corporate governance, semakin meningkatkan kualitas informasi akuntansi dari sudut pandang users.

\section{PEMBAHASAN}

Teori keagenan menjelaskan hubungan kontraktual antara pemilik (principals) dan penerima amanat (agents). Pemilik adalah pihak yang memberikan mandat kepada pihak lain (agen), untuk melakukan semua kegiatan atas nama prinsipal dalam kapasitasnya sebagai pengambil keputusan. Praktik pemberian mandat oleh pemilik kepada agen awalnya dijelaskan oleh Berle dan Means (1932) yang menyatakan bahwa perkembangan perusahaan membawa konsekuensi diperlukannya pemisahan antara kepemilikan dan kontrol manajemen atas suatu perusahaan modern, sehingga tercipta suatu mekanisme pengawasan kepada agen untuk bertindak sesuai dengan kepentingan pemilik perusahaan. Pemikiran dari Berle dan Means masih relevan sampai sekarang dalam konteks pengelolaan perusahaan modern sekalipun. Mekanisme pengawasan terhadap agen dimaksudkan untuk melakukan kontrol terhadap tindakan-tindakan agen dan keputusan yang diambil sesuai dengan kepentingan pemilik perusahaan. Lemahnya pengawasan terhadap agen mendorong pihak manajemen untuk berperilaku sesuai dengan kepentingannya.

Pemikiran dari Berle dan Means, selanjutnya dikembangkan oleh Jensen dan Meckling (1976) dengan memperkenalkan apa yang dikenal dengan "agency theory". Teori ini sampai sekarang masih relevan untuk menjelaskan variabel-variabel yang diteliti khususnya bidang akuntansi keuangan dan pasar modal. Dalam mendefinisikan hubungan keagenan (agency relationship), Jensen dan Meckling (1976) menyatakan bahwa hubungan keagenan itu sebagai suatu kontrak yang dilakukan oleh satu orang atau lebih (dalam hal ini pemilik atau prinsipal) dan orang lain (dalam hal ini selaku agen atau penerima amanat), untuk melakukan kegiatan atau jasa (service) yang sudah didelegasikan dan mengambil keputusan yang menjadi kewenangannya.

Eisenhard (1989) mengungkapkan bahwa yang menjadi fokus pada teori keagenan adalah tentang: 1) bagaimana menentukan kontrak yang paling efisien yang mengatur pola hubungan antara prinsipal dengan agen, dengan beberapa asumsi sifat manusia yang lebih cenderung mementingkan diri sendiri (self interest), memiliki keterbatasan rasional (bounded rationality) seperti keterbatasan informasi, pengetahuan terbatas), dan cenderung menghindari risiko; 2) tentang organisasi yang di dalamnya terdapat potensi konflik kepentingan antar anggotanya; dan 3) tentang informasi, yang mana informasi adalah suatu komoditi dan dapat dibeli. Dari penjelasan Eisenhard tersebut, hubungan keagenan dapat dilihat dari dua sudut pandang, yaitu 1) secara ekonomi, teori agensi 
memprediksi dan menjelaskan perilaku pihak-pihak yang terlibat dengan perusahaan, 2) secara hukum, agen adalah seseorang yang dipekerjakan untuk kepentingan pihak lain yang diikat dalam perjanjian kontraktual.

Perkembangan teori akuntansi sejak tahun 1930an sampai 1970-an cenderung akuntansi normatif (normative accounting theory), dalam hal ini teori akuntansi lebih banyak mengkaji bagaimana seharusnya akuntansi berjalan dan tidak menjelaskan mengapa hal itu terjadi. Teori normatif berusaha menjelaskan informasi apa yang seharusnya dikomunikasikan kepada pemakai informasi akuntansi dan bagaimana informasi tersebut akan disajikan. Jadi teori normatif berusaha menjelaskan apa yang seharusnya dilakukan oleh akuntan (what ought to be) dalam proses penyajian informasi keuangan kepada para pemakai dan bukan menjelaskan tentang apakah informasi keuangan itu (what is) atau mengapa hal itu terjadi.

Teori normatif ini mulai dipertanyakan kembali relevansinya terutama pada pertengahan tahun 60 -an, dengan munculnya hipotesis pasar modal yang efisien (efficient market hypotesis), yang akhirnya memunculkan gagasan yang berlawanan dengan konsep teori normatif. Watts dan Zimmerman (1990) mengemukakan pandangan lain yang dikenal dengan Teori Akuntansi Positif (Positive Accounting Theory), sebagai suatu dasar pemikiran untuk menganalisis teori akuntansi dalam pendekatan normatif terlalu sederhana dan tidak memberikan dasar teori yang kuat.

Teori Akuntansi Positif memfokuskan pada kemampuan untuk menjelaskan dan memprediksi praktik-praktik akuntansi. Teori ini bermanfaat untuk memahami dan memprediksi perubahan akuntansi perusahaan. Kebijakan akuntansi yang dirumuskan oleh pihak manajemen, substansinya adalah dalam rangka merespon usulan standar akuntansi yang baru. Hal ini sejalan dengan apa yang disampaikan oleh Scott (2009), bahwa:

Positive accounting theory (PAT) is concerned with predicting such actions as the choices of accounting policies by the firm managers and how managers will respond to proposed new accounting standards.

PAT memiliki pandangan bahwa perusahaan memiliki kemampuan untuk mengorganisasi penggunaan sumber daya secara efisien dan efektif dalam rangka memaksimalkan prospek perusahaan dan menjaga kelangsungan usaha. Perusahaan dapat dipandang sebagai serangkaian kontrak (a nexus of contract) yang memiliki konsekuensi ekonomi.
Jensen dan Meckling (1976) menyatakan bahwa perusahaan berusaha untuk meminimalisasi biaya kontrak yang dilakukan dengan pihak eksternal. Kontrak-kontrak tersebut dapat dilakukan dengan karyawan, kreditor, investor, supplier dan pihak lainnya. Scott (2009) mengemukakan bahwa banyak kontrak yang dilakukan perusahaan berhubungan dengan variabel-variabel akuntansi. Kontrak dengan karyawan dalam kaitannya dengan promosi dan remunerasi didasarkan pada variabel pencapaian laba bersih perusahaan atau biaya standar. Kontrak dengan pemasok (supplier) dihubungkan dengan variabel likuiditas dan pembiayaan perusahaan. Kreditor mensyaratkan proteksi dalam bentuk dipenuhinya rasio-rasio keuangan seperti rasio hutang terhadap aset, rasio hutang terhadap ekuitas, modal kerja minimal dan sebagainya.

PAT berasumsi bahwa manajer bersifat rasional seperti halnya investor, dan tentunya manajer akan memilih kebijakan akuntansi yang paling menguntungkan kepentingannya, jika memang bisa dilakukan. PAT tidak mengasumsikan bahwa manajer akan sungguh-sungguh berbuat untuk memaksimalkan keuntungan perusahaan. Prediksi yang dilakukan dalam teori akuntansi positif umumnya berkisar pada tiga hipotesis pengontrakan seperti yang diformulasikan oleh Watts and Zimmerman (1990) yaitu hipotesis rencana bonus (bonus plan hypothesis), perjanjian hutang (debt covenant) dan political cost.

Manajemen laba muncul pada saat peneliti akuntansi dan manajemen keuangan mencoba meneliti hubungan antara variabel-variabel ekonomi tertentu dan upaya manajer untuk mengambil manfaat atas variabel tersebut. Hal ini berkaitan erat dengan teori akuntansi positif dari Watts dan Zimmerman (1990) yang menjelaskan bahwa suatu teori akuntansi yang berusaha mengungkapkan faktor-faktor ekonomi tertentu atau ciri-ciri suatu unit usaha tertentu bisa dikaitkan dengan perilaku manajer atau para pembuat laporan keuangan.

Manajemen laba merupakan salah satu faktor yang dapat mengurangi kredibilitas laporan keuangan, menambah bias dalam laporan keuangan dan dapat mengganggu pemakai laporan keuangan yang mempercayai angka laba hasil rekayasa tersebut sebagai angka laba tanpa rekayasa. Manajemen laba yang berlebihan akan mengurangi usefulness laporan keuangan dalam pandangan penanam modal (Scott, 2009: 403).

Munculnya praktik manajemen laba karena manajer memiliki akses informasi yang lebih dibandingkan dengan pihak lainnya. Jansen dan Meckling (1976) dan Watts dan Zimmerman (1990) menyatakan bahwa laporan keuangan yang dibuat 
dengan angka-angka akuntansi diharapkan dapat meminimalkan konflik di antara pihak-pihak yang berkepentingan. Dengan laporan keuangan yang dilaporkan oleh agen sebagai pertanggungjawaban kinerjanya, principal dapat menilai, mengukur, dan mengawasi sampai sejauh mana agen tersebut bekerja untuk meningkatkan kesejahteraannya, serta memberikan kompensasi kepada agen.

Beberapa pendapat yang mengatakan bahwa manajemen laba dilakukan karena didorong oleh adanya kepentingan-kepentingan pribadi manajer. Healey (1985) dalam papernya yang berjudul "the effect of Bonus Schemes on Accounting Decisions" mengungkapkan bahwa manajer melakukan manajemen laba untuk memaksimalkan kepentingan bonus manajer. Schipper (1989) mengungkapkan bahwa manajemen laba dianggap sebagai suatu intervensi pihak manajemen dengan tujuan tertentu dalam proses pelaporan keuangan (financial reporting) untuk pihak eksternal, dengan tujuan untuk memperoleh beberapa keuntungan pribadi. Mempertegas pendapat sebelumnya, Belkaoui (2004) menyatakan bahwa manajemen laba adalah potensi penggunaan manajemen akrual dengan tujuan untuk memperoleh keuntungan pribadi.

Scott (2009) pandangan yang lebih luas tentang manajemen laba mengungkapkan bahwa manajemen laba dapat dipandang menjadi dua perspektif yaitu: 1) perspektif pelaporan keuangan (financial reporting), yang mana dalam perspektif ini manajer menggunakan manajemen laba untuk kepentingan peramalan atas laba sehingga akan terhindar dari reaksi negatif para investor, dan 2) perspektif kontraktual (contracting perspective), yang mana dalam perspektif ini manajer menggunakan manajemen laba untuk melindungi diri mereka dan perusahaan dalam mengantisipasi kejadian-kejadian yang tak terduga untuk keuntungan pihak-pihak yang terlibat dalam kontrak. Dengan demikian, manajer dapat mempengaruhi nilai pasar saham perusahaannya melalui manajemen laba, misalnya dengan membuat perataan laba (income smoothing) dan pertumbuhan laba sepanjang waktu. Scott (2009), mendefinisikan manajemen laba adalah sebagai berikut: "Earnings management is the choice by a manager of accounting policies, or actions affecting earnings, so as to achieve some specific reported earnings objective."

Isu good corporate governance dilatar belakangi oleh adanya konflik kepentingan antara pemilik (principal) dan pihak manajemen, dan antara pemegang saham mayoritas dan pemegang saham minoritas. Manajer berperan sebagai agen dalam suatu perusahaan dan diberi kewenangan untuk mengurus jalannya perusahaan dan mengambil keputusan atas nama pemilik. Dengan superioritas informasi yang dimilliki oleh manajer, memungkinan manajer memiliki kepentingan yang berbeda dengan pemegang saham (pemilik).

Kata 'governance' diterjemahkan oleh Komite Nasional Kebijakan Governance (KNKG) sebagai 'tata kelola'. 'Governance' berbeda dengan 'management'. Lukviarman (2005) berpendapat bahwa manajemen berhubungan dengan manage the things, sehingga merupakan mekanisme yang akan menjamin bahwa segala sesuatu "dilakukan secara benar" (doing things right), sedangkan governance merupakan mekanisme untuk melakukan "sesuatu yang benar" (doing the right things).

Para ahli dalam memberikan pendapat terhadap Corporate Governance berbeda-beda tetapi secara substansi memiliki makna yang sama. Morck et al. (1989) mengemukakan bahwa corporate governance merupakan suatu mekanisme yang dapat digunakan untuk memastikan bahwa supplier keuangan atau pemilik modal perusahaan memperoleh pengembalian (return) dari kegiatan yang dijalankan oleh manajer, atau dengan kata lain bagaimana supplier keuangan perusahaan melakukan pengendalian terhadap manajer. Pendapat ini lebih memberikan perhatian kepada pemilik modal (supplier keuangan) terhadap return yang diharapkan atas dana yang diinvestasikan. Pihak manajer, selaku penerima amanah, harus menjaga kepentingan dari pemilik modal. Corporate Governance yang lebih menekankan pada seperangkat regulasi yang mengatur pola hubungan antara pemegang saham, manajer, kreditor, tenaga kerja dan para pihak pemangku kepentingan lainnya dikemukakan oleh Cadbury Committee (Cadbury, 1992) dan OECD (2004), sebagai berikut:

Cadbury Committee (Cadbury, 1992): Corporate Governance is a set of the rules that define a relationship between shareholders, manager, creditor, the government, employees and other internal and external stakeholder in respect to their rights and responsibilities.

Organization for Economic Cooperation and Development (OECD) (2004): mendefinisikan Corporate Governance sebagai seperangkat peraturan yang menetapkan hubungan antara pemegang saham, pengurus, pihak kreditor, pemerintah, karyawan serta pemangku kepentingan lainnya sehubungan dengan hak-hak dan kewajiban mereka, atau dengan kata lain sistem yang mengarahkan dan mengendalikan perusahaan.

IICG (2012) mendefinisikan Good Corporate Governance sebagai struktur, sistem, dan proses yang digunakan oleh organ-organ perusahaan sebagai 
upaya untuk memberikan nilai tambah perusahaan secara berkesinambungan dalam jangka panjang, dengan tetap memperhatikan kepentingan stakeholder lainnya, berlandaskan peraturan perundangan dan norma yang berlaku.

Keberadaan struktur dalam organisiasi lebih ditekankan pada bagaimana aktivitas dalam organisasi dibagi, diorganisir, dan dikoordinasi (Stoner et al. 1995). GCG, sebagai suatu struktur dimaknai bahwa elemen-elemen yang membentuk GCG (dewan komisaris, komite audit, direksi dan pemegang saham) berperan sesuai dengan hak dan kewajiban masing-masing. Struktur corporate governance harus didesain untuk mendukung jalannya aktivitas organisasi secara bertanggungjawab dan terkendali dengan mengacu pada prinsip-prinsip GCG (Tranparansi, Akuntabilitas, Responsbility, Independensi, dan Fairness).

Disain struktur CG berkaitan dengan model sistem hukum yang dianut oleh suatu negara. Negaranegara yang menganut model hukum Anglo-Saxon, struktur CG tidak memisahkan keanggotaan dewan komisaris dan dewan direksi, model ini dikenal dengan single board system. Perusahaan-perusahaan di Inggris, Amerika dan negara-negara lain yang basis hukumnya menganut model Ango-Saxon, struktur corporate governance terdiri dari RUPS, board of directors (representasi dari pemegang saham) dan executive managers (merupakan pihak manajemen yang menjalankan aktivitas operasi perusahaan. Berikut adalah gambar struktur corporate governance dengan single board system (Tjager et al., 2003 dan Syakhroza, 2005):

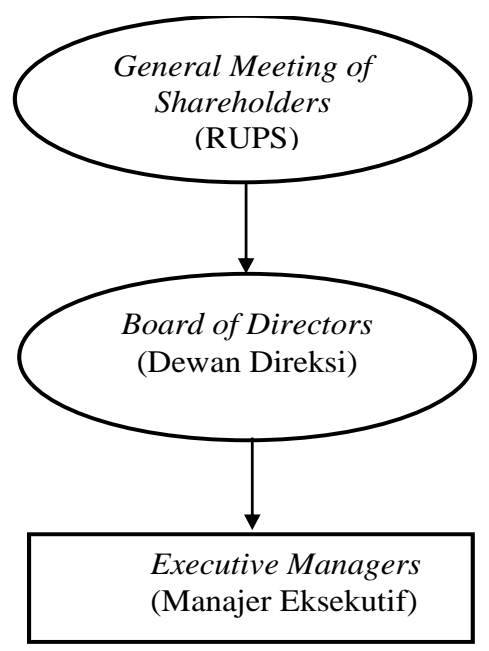

Gambar 1. Struktur CG-Single Board System (Model Anglo Saxon)

Bagi negara-negara yang menganut Model Continental Europe, struktur CG disebut dengan two board system yang terdiri dari RUPS, Dewan
Komisaris, Dewan Direktur dan Manajer Eksekutif (selaku pihak manajemen). Dalam two board system secara tegas adanya pemisahan keanggotaan dewan yaitu keanggotaan dewan komisaris sebagai pengawas dan dewan direksi selaku pihak yang mengelola perusahaan (eksekutif). RUPS adalah struktur tertinggi yang mengangkat dan memberhentikan dewan komisaris. Dewan komisaris memiliki kewenangan untuk mengangkat dan memberhentikan dewan direksi serta melakukan fungsi pengawasan terhadap direksi dalam mengelola perusahaan. Berikut adalah struktur corporate governance dengan two board system dengan (Tjager et al., 2003 dan Syakhroza, 2005):

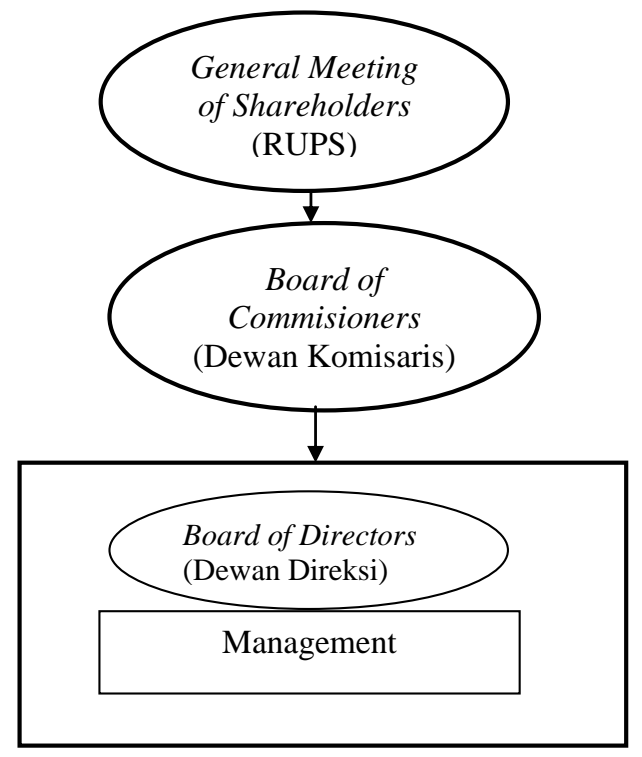

\section{Gambar 2. Struktur CG-Two Board System (Model} Cotinental Europe)

Di Indonesia, struktur CG diatur dalam UU PT no 40 tahun 2007. Secara umum, perusahaanperusahaan di Indonesia struktur CG berbasis two board system. Perbedaan mendasar terletak pada kedudukan dewan komisaris yang tidak langsung membawahi direksi. Hal ini sesuai dengan aturan dalam UU PT no 40 tahun 2007 bahwa anggota dewan direksi diangkat dan diberhentikan oleh RUPS (pasal 94 ayat 1 dan pasal 105 ayat1). Selain itu, kedudukan anggota dewan komisaris juga diangkat dan diberhentikan oleh RUPS (pasal 111 ayat 1). Dengan demikian, maka baik anggota direksi maupun anggota dewan komsaris bertanggungjawab pada RUPS. Struktur CG yang menempatkan dewan komisaris dan dewan direksi sejajar berdampak pada kurang efektifnya fungsi pengawasan karena dewan direksi beranggapan sebagai mitra kerja. Berikut adalah gambar struktur corporate governance untuk 
perusahaan-perusahaan Indonesia dengan mengacu pada UU PT no 40 tahun 2007.

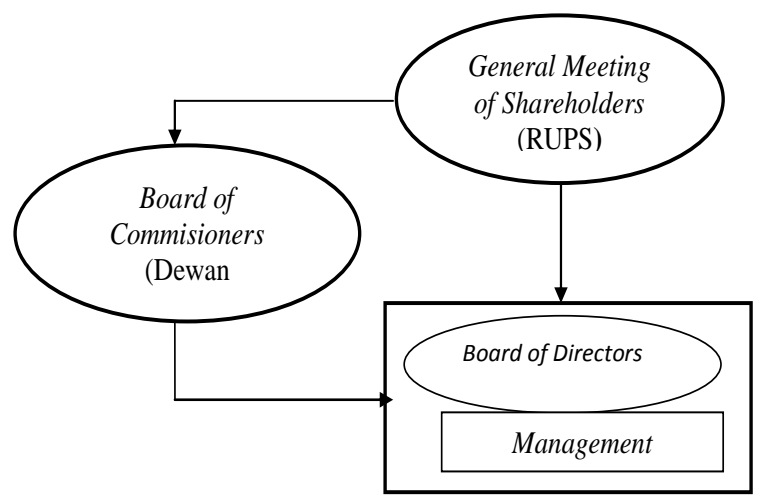

Gambar 3. Struktur CG di Indonesia (Dual Board System)

Kepemilikan institusional merupakan kepemilikan saham oleh sebuah lembaga (baik lembaga pemerintah maupun lembaga swasta) yang memiliki kepentingan besar terhadap investasi yang dilakukannya. Pemilik institusional memiliki beberapa kelebihan dibandingkan dengan investor lainnya. Umumnya institusi menyerahkan tanggungjawab untuk mengelola investasi pada divisi tertentu, sehingga institusi dapat memantau secara profesional perkembangan investasinya. Dengan demikian, praktik manajemen laba dapat ditekan melalui efektivitas pengawasan yang dilakukan oleh pemegang saham institusi.

Hasil studi empiris yang mengungkapkan bahwa hubungan variabel kepemilikan insitusional dengan manajemen laba memiliki asosiasi negatif adalah riset yang dilakukan oleh Chung et al. (2002), Midiastuty dan Machfoedz (2003), Park dan Shin (2004), Hsu dan Koh (2005), Cornett et al., (2009) dan Koh (2007). Artinya semakin besar saham dimiliki oleh pemegang saham insitusional, maka semakin kecil praktik manajemen laba yang yang dilakukan oleh pihak manajer. Argumentasi yang dikemukakan terhadap temuan studi empiris ini adalah investor institusional memiliki keunggulan dalam akses informasi, adanya divisi tertentu yang khusus memfokuskan pada investasi, keunggulan sumber daya manusia dan infrastruktur. Dengan demikian, mereka memiliki kemampuan melakukan monitoring lebih baik dari investor lainnya, sehingga dapat membuat pihak manajemen lebih berhati-hati dalam melakukan aktivitasnya sehingga kinerja perusahaan menjadi lebih baik.

Hasil berbeda ditunjukkan oleh Siregar dan Utama (2005) yang tidak menemukan bukti adanya pengaruh kepemilikan institutional yang signifikan terhadap rekayasa laba. Kepemilikan saham institusional merupakan salah satu elemen dalam implementasi struktur corporate governance. Hasil penelitian ini bisa dimaknai keberadaan pemegang saham insitusional tidak dapat mengurangi potensi praktik rekayasa laba dilakukan oleh manajer. Argumentasi dari hasil penelitian ini bisa jadi disebabkan bahwa di Indonesia, pemegang saham institusional masih merupakan bagian saham pendiri perusahaan. Dengan demikian, efektivitas monitoring tidak bisa berjalan dengan maksimal.

Peningkatan kepemilikan saham oleh manajer diharapkan akan membuat manajer bertindak sesuai dengan keinginan principal karena itu manajer akan termotivasi untuk meningkatkan kinerja. Menurut Jensen dan Meckling (1976), kepemilikan manajerial adalah mekanisme corporate governance utama yang membantu mengendalikan masalah-masalah keagenan (agency problems). Kepemilikan manajerial yang tinggi dapat digunakan untuk mengurangi masalahmasalah keagenan. Peningkatan proporsi saham yang dimiliki oleh manajer akan menurunkan kecenderungan manajer untuk melakukan tindakantindakan yang berorientasi untuk kepentingan pribadi (oportunistic behaviour). Dengan kata lain, kepentingan manajer dan pemegang saham dapat diselaraskan bila manajer memiliki saham perusahaan yang lebih (Morck et al., 1989).

Studi empiris asosiasi antara kepemilikan manajemen (manajerial) dan manajemen laba telah dilakukan oleh beberapa peneliti dengan hasil yang tidak konsisten. Beberapa hasil studi yang menunjukkan bahwa kepemilikan manajerial berhubungan negatif dengan manajemen laba (yang diukur dengan discretionary accruals) dilakukan oleh Dhaliwal (1980), Morck et al. (1989), Warfield et al. (1995) dan Midiastuty dan Mahfoedz (2003). Argumentasi yang dapat dikemukakan dari hasil studi ini adalah jika manajer perusahaan juga sekaligus sebagai seorang pemegang saham (shareholders), maka dimungkinkan terjadi keselerasan kepentingan antara pemilik dan pihak manajemen. Dengan demikian, potensi konflik keagenan yang terjadi antara pihak manajemen dan pemilik perusahaan dapat diminimalisasi.

Hasil berbeda diungkapkan oleh Gabrielsen et al. (2002) dan Gideon (2005) bahwa adanya pengaruh positif signifikan kepemilikan manajerial terhadap manajemen laba. Dengan kata lain, semakin tinggi tingkat kepemilikan saham oleh pihak manajemen, maka semakin besar manajer untuk melakukan praktik manajemen laba. Praktik manajemen laba tetap terjadi meskipun sebagian saham dimiliki oleh manajer. Argumentasi yang dapat 
dikemukakan adalah manajer melakukan praktik manajemen laba dalam rangka untuk memaksimalkan kepentingan bonus dirinya. Kesejahteraan manajer sangat tergantung dari seberapa besar kinerja yang dapat dicapai dalam suatu periode akuntansi. Konsekuensinya adalah manajer akan memilih kebijakan akuntansi yang berdampak pada peningkatan kinerja perusahaan.

Keahlian dan kapasitas yang dimiliki oleh dewan komisaris dari unsur independen diharapkan dapat meningkatkan efektivitas pengawasan. Pengawasan yang efektif dapat menjamin bahwa tindakan yang dilakukan oleh manajer merupakan representasi dari kepentingan pemegang saham (shareholders). Hasil studi empiris yang mendukung terhadap proporsi dewan komisasris independen dapat mengurangi manajemen laba dilakukan oleh Beasley (1996), Dechow et al. (1996), Peasnell et al. (2005), Klein (2002), Nasution dan Setyawan (2007), Chen et al. (2007) dan Cornet et al. (2009). Justifikasi yang dapat dikemukan dari hasil studi ini adalah keberadaan komisaris independen dapat meningkatkan efektivitas pengawasan terhadap pihak manajemen. Dengan demikian, potensi manajer untuk melakukan praktik manajemen laba dapat ditekan.

Namun, studi yang dilakukan oleh Park dan Shin (2004), Veronica dan Bachtiar (2004), Gideon (2005) tidak menemukan bukti adanya pengaruh proporsi dewan komisaris independen terhadap manajemen laba. Hasil studi ini berbeda dengan sebagian besar hasir riset sebelumnya. Hal ini menunjukkan bahwa keberadaan anggota dewan komisaris independen tidak mampu menekan praktik manajemen laba. Implikasi hasil studi tersebut dalam perspektif praktik good corporate governance di Indonesia menunjukkan bahwa pengangkatan komisaris independen perlu dievaluasi, tidak hanya sebatas memenuhi aspek regulasi saja, tapi yang lebih penting adalah mempertimbangkan unsur keahlian, independensi dan profesionalisme.

Keberadaaan Kantor Akuntan Publik (KAP) yang bereputasi diharapkan dapat mengurangi konflik kepentingan tersebut. KAP bereputasi diyakini memiliki kemampuan profesional dan independensi sehingga dapat menekan kesalahan saji yang bersifat material atas laporan keuangan yang dipublikasikan. Sebagian besar hasil studi empirik membuktikan adanya asosiasi negatif antara kualitas audit dan manajemen laba. Hasil studi tersebut dilakukan oleh Becker et al. (1998), Francis et al. (2006), Lennox (2000), Krishnan dan Schauer (2000), Chen et al. (2007), Veronica dan Bachtiar (2004), Tendeloo dan Vanstraelen (2008), Francis dan Yu (2009) dan Rusman (2010). Justifikasi terhadap hasil studi ini adalah hasil audit yang dilakukan oleh KAP yang bereputasi diyakini dapat meningkatkan kredibilitas laporan keuangan. Dengan demikian, pihak manajer memiliki kecenderungan untuk tidak melalukan rekayasa laba jika menjadi klien KAP besar (KAP) bereputasi.

Sementara itu, hasil studi yang dilakukan oleh Jeong dan Rho (2004) dan Tendeloo dan Vanstraelen (2008) membuktikan bahwa kualitas audit tidak berpengaruh terhadap manajemen laba. Artinya manajer tetap melakukan praktik manajemen laba meskipun menjadi Klien KAP besar. Alasannya adalah praktik manajemen laba menjadi kewenangan manajer (discretionary management) dan tidak melanggar Prinsip-prinsip Akuntansi Yang Berterima Umum (PABU).

\section{SIMPULAN DAN SARAN}

Berdasarkan uraian teoritis dan bukti empiris sebagaimana telah diuraikan sebelumnya, maka ada beberapa simpulan penting yang dapat dikemukakan. Pertama, struktur corporate governance (diproksi dengan kepemilikan insitusional, kepemilikan manajemen dan komisaris baik unsur independen maupun tidak) diharapkan dapat meningkatkan kualitas informasi akuntansi. Kedua, manajer memiliki kewenangan untuk memilih kebijakan akuntansi tertentu yang tidak hanya berdampak pada kinerja perusahaan, tetapi juga didorong oleh kepentingan pribadi manajer yang dapat dikatakan bersifat opportunisctic behavior. Ketiga, sebagian besar bukti empiris menunjukkan bahwa keberadaan kepemilikan institusi, kepemilikan manajemen, komisaris independen dan Kantor Akuntan Publik (KAP) bereputasi mampu menekan potensi praktik manajemen laba. Keempat, Scott (2009) menyimpulkan bahwa pendekatan decision usefulness dari sisi teori akuntansi adalah jika tidak dapat mempersiapkan laporan keuangan secara teoritis benar, setidaknya kita dapat mencoba membuat laporan keuangan lebih berguna (more useful). Artinya praktik manajemen laba akan berdampak pada kredibilitas laporan keuangan. Praktik manajemen laba yang berlebihan akan berpengaruh terhadap kredibilitas laporan keuangan dari sudut pandang investor.

Menyikapi bahwa telah banyak penelitian empiris yang menghubungkan corporate governance dengan manajemen laba, maka tetap masih terbuka peluang untuk dilakukan riset lanjutan dengan beberapa modifikasi seperti penggunaan proksi yang berbeda terhadap pengukuran corporate governance dan lebih memfokuskan pada industri tertentu (suatu misal industri perbankan atau industri manufaktur). 
Pertimbangannya adalah pemilikan kebijakan akuntansi bisa jadi berbeda praktik earnings management antar satu perusahaan dengan perusahaan yang lain.

Penyusunan Standar Akuntansi Keuangan sudah mengacu pada International Financial Reporting Standards (IFRS). Konsekuensinya adalah adanya beberapa perubahan dalam Pernyataan Standar Akuntansi Keuangan (PSAK). Harmonisasi terhadap PSAK dengan IFRS ini bisa jadi berpengaruh terhadap manajemen laba dan financial reporting. Karena itu, sosialiasai terhadap SAK baru menjadi penting bagi manajer perusahaan.

Isu Corporate Governance dan manajemen laba berkaitan dengan perilaku. Dengan demikian, pendekatan non mainstream (paradigma kualitatif) menjadi alternatif untuk mengungkap lebih detail terhadap motivasi manajer dalam melakukan praktik manajemen laba. Selain itu, praktik corporate governance yang ada sekarang apakah merupakan suatu kebutuhan perusahaan, sebagai corporate culture, ataukah sebatas memenuhi aspek regulasi. Karena itu, observasi langsung terhadap informan menjadi pilihan lain untuk mengungkap masalah ini.

\section{DAFTAR REFERENSI}

Beasley, M.S., 1996. An Empirical Analysis of The Relation Between The Board of Director Composition and Financial Statement Fraud. The Accounting Review 71(4): 443-465.

Becker, C., DeFond, M., Jiambalvo, J. \& Subramanyam, K. 1998. The Effect of Audit Quality on Earning Management. Contemporary Accounting Research, 15(1): 1-24.

Belkaoui, A. R. 2004. Accounting Theory. Jakarta: Salemba Empat.

Berle, A. \& Means, G. 1932. The Modern Corporation and Private Property. New York: MacMillan.

Cadbury, A. 1992. Committee on the Financial Aspects of Corporate Governance, Section 2.5, $\mathrm{p}-15$, Gee and Co. Ltd, C/O, The London Stock Exchange, United Kingdom, (http://www.ecgi. org/codes/documents/cadbury.pdf, diakses 1 Juli 2012).

Chen, K.Y., Elder, R..J. \& Hsieh, Y.M. 2007. Corporate Governance and Earnings Management: The Implications of Corporate Governance BestPractice Principles for Taiwanese Listed Companies, Working Papers http://ssrn.com/: 147.

Chung, R., Firth, M. \& Kim, J. B. 2002. Institutional Monitoring and Opportunistic Earnings Management. Journal of Corporate Finance, 8: 2948.
Cornett, M.M., McNutt, J.J. \& Tehranian, H. 2009. Corporate Governance and Earnings Management at large U.S Bank Holding Companies. Journal of Corporate Finance, 15 :412-430.

Dechow, P.M., Sloan, R.G. \& Sweeney, A.P. 1996. Causes and Consequences of Earnings Manipulaton: An Analysis of Firms Subject to Enforcement Actions by the SEC. Contemporary Accounting Research, 13: 1-36.

Dhaliwal, D.S. 1980. The Effect of the Firm's Capital Structure on the Choice of Accounting Methods. Accounting Review, 55(1): 78-84.

Eisenhard, K.M. 1989, Agency Theory: An Assessment and Review. Academic of Management Review, 14(1): 15-74.

Francis, J., Olsson, P. \& Schipper, K. 2006. Earnings Quality, Foundation and Trend in Accounting, SSRN.

Francis, J.R. \& Yu., M.D. 2009. Big 4 office Size and Audit Quality, The Accounting Review 84(5): 1521-1552.

Gabrielsen, G., Gramlich, J.D. \& Plenborh, T. 2002. Managerial Ownership, Information Content of Earnings and Discretionary Accruals in a Non US Setting. Journal of Business Finance and Accounting, 29(7\&8): 967-988.

Gideon S.B. 2005. Kualitas Laba: Studi Pengaruh Mekanisme Corporate Governance dan Dampak Manajemen Laba dengan Menggunakan Analisa Jalur. Makalah. Simposium Nasional Akuntansi $I X$.

Healy, P.M. 1985. The Effect of Bonus Schemes on Accounting Decisions. Journal of Accounting and Economics, 7(1-3): 85-107.

Hsu, G.C.M. \& Koh, P.S. 2005. Does the Presence of Institutional Investors Influence Accruals Management? Evidence from Australia. Corporate Governance: An International Review, 13(6): 809-823.

IICG. 2012. Tata Kelola, (http://iicg.org/iicg/home. php?type=1\&pageno=3, diakses 1 Juli 2012).

Jensen, M. C. \& Meckling, W.H. 1976. Theory of the Firm: Managerial Behavior, Agency Cost and Ownership Structure. Journal of Financial Economics, 3(4):305-360.

Jensen, M.C. 1993. The Modern Industrial Revolution, Exit, and the Failure of Internal Control Systems. The Journal of Finance, 48(3): 831880.

Jeong, S.W. \& Rho, J. 2004. Big Six auditors and audit quality: The Korean Evidence. the International Journal of Accounting, 39: 175196. 
Klein, A. 2002. Audit Committee, Board of Director Characteristic, and Earnings Management. Journal of Accounting and Economics, 33: 375400.

Koh, P.S., 2007. Institutional Investor Type, Earnings Management and Benchmark Beaters in Australia. Journal of Accounting and Public Policy, 26: $267-299$.

Krishnan, J. \& Schauer, P.C. 2000. The Differentiation of Quality Among Auditors: Evidence from the Not-for-Profit Sector. Auditing: A Journal of Practice \& Theory, 19(2): 9-25.

Lennox, C. 2000. Do Companies Successfully Engage in Opinion Shopping: Evidence from The UK? Journal of Accounting and Economics, 29: 321-337.

Lukviarman, N. 2005. Perspektif Shareholding Versus Stakeholding Dalam Memahami Fenomena CG. Yogyakarta.

Magnan, M. \& Cormier, D. 1997. The Impact of Forward-Looking Financial Data in IPOs on the Quality of Financial Reporting. Journal of Financial Statement Analysis: 6-17.

Midiastuty, P.P. \& Machfoedz, M., 2003. Analisis Hubungan Mekanisme Corporate Governance dan Indikasi Manajemen Laba. Simposium Nasional Akuntansi 6 Surabaya.

Morck, R., Shleifer, A. \& Vishny, R.W. 1989. Alternative Mechanism for Corporate Control. American Economics Review, 79: 842-852.

Nasution, M., \& Setyawan, D. 2007. Pengaruh Corporate Governance Terhadap Manajemen Laba di Industri Perbankan Indonesia. Makalah SNA X di Makasar.

OECD, 2004. Corporate Governance; A Survey of OECD Countries. OECD Publication Service, France.

Park, Y.W. \& Shin, H.H. 2004. Board Composition and Earnings Management in Canada. Journal of Corporate Finance, 10: 431-457.

Peasnell, K.V., Pope, P.F. \& Young, S. 2005. Board Monitoring and Earnings Management: Do Outside Directors Influence Abnormal Accruals. Journal of Business Finance and Accounting, 32 (7\&8): 1311-1346.
Rusman. 2010. Model-Model Pembelajaran. Bandung: Mulia Mandiri Press.

Schipper, K. 1989. Earnings Management. Accounting Horizons, 3 (4): 91-102. Retrieved: February 3rd, 2007, from ProQuest database.

Scott, W.R. 2009. Financial Accounting Theory. Fifth Edition, University of Waterloo: Queen's University.

Siregar, S.V. \& Utama, S. 2005. Pengaruh Struktur Kepemilikan, Ukuran Perusahaan, dan Praktik Corporate Governance Terhadap Pengelolaan laba. Kumpulan Makalah, Simposium Nasional Akuntansi (SNA) VIII.

Stoner, J., Freeman, E. \& Gilbert, D. 1995. Management. $6^{\text {th }}$ ed. Englewood Cliffs, NJ: Prentice Hall, Inc.

Syakhroza, A. 2005. Corporate Governance: Sejarah dan Perkembangan, Teori, Model dan Sistem Governance serta Aplikasinya pada Perusahaan BUMN. Pidato Pengukuhan Guru Besar. Universitas Indonesia. Jakarta.

Tendeloo, B.V. \& Vanstraelen, A. 2008. Earnings Management and Audit Quality in Europe: Evidence from the Private Client Segment Market. European Accounting Review 17(3): 447-469.

Tjager, I.N., Alijoyo, F.A., Djemat, H.R. \& Somebodo, B. 2003. Corporate Governance: Tantangan dan Kesempatan Bagi Komunitas Bisnis Indonesia. Jakarta: PT. Prenhallindo.

Veronica, S. \& Bachtiar, Y.S. 2004. Good Corporate Governance Information Asymetry dan Earnings Management. Simposium Nasional Akuntansi 7 Denpasar.

Warfield, T.D., Wild, J.J. \& Wild, K. 1995. Managerial Ownership, Accounting Choices and Informativeness of Earning. Journal of Financial Economics, 50: 61-91.

Watts, R.L. and J.L. Zimmerman. 1990. Positive Accounting Theory; A Ten Year Perspective. Accounting Review, 65 (1): 131-156.

Zarkasyi, M. W. 2008. Good Corporate Governance: Pada Badan Usaha Manufaktur, Perbankan, dan Jasa Keuangan Lainnya. Bandung: Alfabeta. 